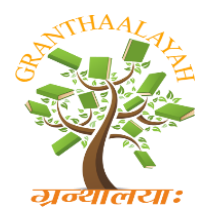

INTERNATIONAL JOURNAL OF RESEARCH GRANTHAALAYAH

A knowledge Repository

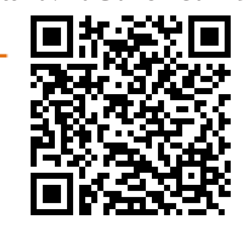

Social

\title{
RE-READING THE DEAD CHILD: THE POST-HOLOCAUST RECEPTION OF THE DIARY OF ANNE FRANK
}

\author{
Mr. Rajarshi Mukherjee ${ }^{* 1}$, Miss. S. Chakraborty ${ }^{2}$ \\ ${ }^{*}$ Assistant Professor, Department of English, Shyampur Siddheswari Mahavidyalaya, Ajodhya \\ Howrah-711312, INDIA \\ ${ }^{2}$ Contractual Lecturer, Department of English, Vivekananda College for Women, Barisha \\ Kolkata- 700008, INDIA
}

\begin{abstract}
This paper aims to focus on the reception of The Diary of Anne Frank in the post-Holocaust era. While as a personal narrative The Diary has been immensely successful in acquiring the sympathy of the reader towards the teenaged victim and her family, it has been far from being beyond the realm of criticism. The apparently simple diary of the traumatized teenaged holocaust victim has sparked off revisionist and anti-Semitic debates and discussions which problematizes not only the premises of the composition, but the authorship as well.
\end{abstract}

Keywords:

Holocaust, Anne Frank, Theodor Adorno, George Steiner, Revisionism, Bruno Bettelheim, Meyer Levin, Ditlieb Felderer, Anti-Semitism.

Cite This Article: Mr. Rajarshi Mukherjee, and Miss. S. Chakraborty, "RE-READING THE DEAD CHILD: THE POST-HOLOCAUST RECEPTION OF THE DIARY OF ANNE FRANK" International Journal of Research - Granthaalayah, Vol. 4, No. 3 (2016): 159-163.

\section{INTRODUCTION}

The secondary texts concerning the study of Anne Frank's Diary are numerous. However, the work of Gilmer Sander's remains the most authoritative launching pad for such an enquiry. A host of primary texts along with secondary texts have been consulted in addition to web resources. The hypothesis has been developed using the methods of observation and comparison. The translation of the German works are available both in book and e-book forms

Anne Frank's account of the changes wrought upon eight people hiding out from the Nazis for two-years during the occupation of Holland, living in constant fear and isolation, imprisoned not only by the terrible outward circumstances of war but inwardly by themselves, made me intimately and shockingly aware of war's greatest evil - the degradation of the human spirit.

-Eleanor Roosevelt.1 
Among the recovered written documents composed during the Jewish Holocaust, the diary kept by Anne Frank and published in extracts by her father Otto Frank in 1947, was the most successful in riveting the attention of the post-World War reading public. Through her diary Anne Frank presented the Jewish author as the silent victim of the Holocaust.

The complications of reading The Diary of Anne Frank can be fathomed by its incorporation into any field of Holocaust studies written by German Jewish survivors during the late 1950s. Theodor Adorno, in an essay on the reconstruction of history, used an anecdote concerning the staging of The Diary to show the limitations of texts in uncovering the actual nature of the Holocaust and its origin. He reports of a German woman who had seen the staged version of The Diary and had said afterwards, deeply moved: "Yes, but that girl at least should have been allowed to live" (143-44). Adorno sees this as a probable first step to an awareness of the nature of the Holocaust, but an awareness that, "although it seems to trivialize the dead," 2 is limited by its focus on a single case and avoids any search for the cause of the tragedy. However, Adorno fails to read into this statement the inherent ambivalence of the response, for it is possible to read it as stating: "We were in general right to kill them, but in this specific case we should have behaved differently." Adorno, a survivor who escaped Germany in 1934, sees here the focus on the individual as faulty as the means of escaping any search for the true roots of the Holocaust. He also points out how the Germans remain unmoved even by this individual fate to examine their own attitude towards the Jews.

\section{THE PROBLEM}

George Steiner, in his essay on the "hollow miracle," reiterates a similar view: "True, German audiences were moved not long ago by the dramatization of The Diary of Anne Frank. But even the terror of The Diary has been an exceptional reminder. And it does not show what happened to Anne inside the camp. There is little market for such things in Germany." ${ }^{4}$ The drama based on The Diary provided the audience in Germany as well as throughout the world with a living victim. It provided the resurrection of one of the dead witnesses of the Holocaust, one who spoke and thus broke through the silence attributed to the victim.

Another authority whose work on the pattern of survival had become a standard in the past decades, Bruno Bettelheim, was born and educated in Vienna and incarcerated in Dachau and Buchenwald during 1938-1939. His study The Informed Heart (1960) was his attempt to see the Holocaust as an outgrowth of modern society. "He views the inability of the Jews to respond to the world of the camps as merely another manifestation of the dehumanization of modern technological society." "As early as 1943 Bettelheim expressed this view in one of the first psychological studies of the Nazi persecution of the Jews. But it was in 1960, only after the tremendous success of the dramatization of The Diary of Anne Frank, that Bettelheim produced a monograph on the Holocaust, a monograph that contained a study of The Diary. In it Bettelheim criticizes Otto Frank for putting his family into the hiding and maintaining, in their hiding place, the idea that life must continue "as nearly as possible in the usual fashion" (Informed Heart 248). Bettelheim castigates the Franks for not hiding individually or providing themselves with weapons to resist their inevitable discovery and deportation. Bettelheim's criticism of the reception of The Diary is aimed at those who wish "to forget the gas chambers and to glorify attitudes of extreme privatization, of continuing to hold onto attitudes as usual even in a 
Holocaust" (Informed Heart 247). He sees the popularity of the book as a part of the denial "that Auschwitz even existed. If all men are good there was never an Auschwitz" (Informed Heart 249).

\section{RE-EXAMINATION OF THE TEXT AND THE CONTEXT}

In his 1979 collection of essays titled Surviving, Bettelheim republished his 1960 essay - 'The Ignored Lesson of Anne Frank'. Here, it becomes clear that Bettelheim is responding to the 'speaking' Anne Frank of the dramatized version, at the conclusion to which she says, in a disembodied voice, "In spite of everything, I still believe that people are really good at heart". "This improbable sentiment is supposedly from a girl who had been starved to death, had watched her sister meet the fate before she did, knew that her mother had been murdered, and had watched untold thousands of adults and children actually being killed. The statement is not justified by anything Anne actually told her diary" (Informed Heart 250) ${ }^{6}$. Bettelheim implies that he knows that the opposite must have been true - that Anne Frank must have lost her individuality in the camps, that she, too, must have been dehumanized. This pessimistic reading of Anne Frank's fate is needed by Bettelheim to explain her failure to survive. Indeed, in the 1960 essay, Bettelheim compares Anne Frank's Diary with the autobiography of another survivor, Marga Minco, whose book Bitter Herbs appeared in 1960. Bettelheim is appalled at the "universal admiration of [the Franks'] way of coping, or rather not coping. The story of little Marga who survived, every bit as touching, remains totally neglected by comparison" (Ignored Lesson 250) It is the living survivor, Bettelheim himself, who is neglected, while the voices of the dead continue to haunt him. Bettelheim's reworking of the earlier excursus on Anne Frank in this later essay repeats many of the earlier claims. It lays directly on the doorstep of the denial of realities of the Holocaust: "If all men are good at heart, there never really was an Auschwitz; nor is there any possibility that it may recur" (Ignored Lesson 250) Bettelheim has created in his image of Anne Frank the source of the denial of the Holocaust, of the father as a "bad"7 Jew, of the speaking witness as the lying witness.

In January 1959, while Bettelheim was writing his long essay on Anne Frank, a German schoolteacher named Lothar Stielau was charged with disseminating anti-Semitic propaganda. Steliau, a member of a neo-Nazi party in Lubeck, had claimed that The Diary of Anne Frank was "a fabrication, created to defame the German people". ${ }^{8}$ Stielau's claim had been published in the party's newspaper in December 1958. He saw in The Diary a mix of sentimentality and pornographic sexuality aimed at showing the German people in the worst possible light. Stielau charged that the holocaust, as portrayed in The Diary, simply had not happened. The court ordered him dismissed from the civil service and removed from his position in the school system. But this was in no way the end of the anti-Semites' denial of the reality of The Diary. In the United States in 1967 an essay repeating most of the charges made against The Diary appeared in H.L.Mencken's American Mercury. The author, Teressa Hendry, labeled The Diary a "fiction"9 and dismissed it as part of the libel against the Germans.

In 1979, the same year in which Bettelheim published his collection - Surviving,

Ditlieb Felderer published a petit monograph entitled Anne Frank's Diary: A Hoax with the virulently anti-Semitic Institute for Historical Review in California. Felderer presents an interesting case. An Austrian Jew born in 1943, he immigrated to Sweden, where he became a 
convert to the Jehovah's Witnesses, who sent him to Germany after the war to document the Nazi crimes against their members who were persecuted as pacifists. His pamphlet on The Diary is one of the most widely circulated of the revisionist documents. Felderer's arguments, while more detailed than the others, are not very different from Stielau's or Hendry's. The basis of all their charges was Meyer Levin's (the first script writer for the stage adaptation of The Diary) claim to have written the authentic version of The Diary - for the stage. This claim was twisted into a claim that Levin actually wrote The Diary. Hendry claims "The Diary of Anne Frank ... has been sold to the public as the actual diary of a young Jewish girl who died in a Nazi concentration camp after two years of abuse and horror. ... Any informed literary inspection of this book would have shown it to have been impossible as the work of a teenager" (Hendry 27). This forms the central thesis of the entire anti-Semitic readings of The Diary of Anne Frank. The claim of Hendry about the fraudulent fabrication of The Diary is repeated in a widely circulated monograph titled Is the Diary of Anne Frank Genuine? by the French revisionist Robert Faurisson, which simply collects the earlier material and arranges it in a systematic order.

\section{CONCLUSION}

Thus, for the anti-Semites, The Diary of Anne Frank has ever have been a further proof of the lying discourse of the Jews. Jews lie, and they lie to profit themselves through the claims of their own annihilation in their creation of "fictions" about themselves. Seen in this light, The Diary of Anne Frank is yet another failed Jewish novel. It fails because it is not a "real" representation of the hidden language of the Jews but rather a literary work that any "informed literary inspection" (Hendry 27) would reveal as a work of fiction written within non-Jewish literary conventions. It can be assumed that the anti-Semitic readings of The Diary are but continuations of older charges of the dissimulation of the Jews. The Diary comes to have a central role in projections of Jewish self-double. This is specially the case with The Diary's role in defining the damaged discourse of the Jew as a force in shaping the identity of the writer who perceives himself or herself as Jewish.

\section{REFERENCES}

[1] Frank, Anne. The Diary of a Young Girl. Trans. B.M.Mooyart-Doubleday. New York: Bantam Books, 1993.

[2] Adorno, Theodor W. "Was bedeutet: Aufarbeitung der Vengangenheit." Eingriffe. By Adorno. Frankfurt: Suhrkamp, 1968.

[3] Gilman, Sander L. The Dead Child Speaks: Reading The Diary of Anne Frank. Studies in American-Jewish literature, Vol. 7, No.1 (Spring 1988), pp.9-25: Penn State university Press, 1988. (http://www.jstor.org/stable/41205671).

[4] Steiner, George. Language and Silence: Essays on Language, Literature, and the Inhuman. New York: Atheneum, 1967.

[5] Gilman, Sander L. The Dead Child Speaks: Reading The Diary of Anne Frank. Studies in American-Jewish literature, Vol. 7, No.1 (Spring 1988), pp.9-25: Penn State university Press, 1988. (http://www.jstor.org/stable/41205671).

[6] Bettelheim, Bruno. "The Ignored Lesson of Anne Frank." 1960. Bettelheim Surviving 246-57. - The Informed Heart: Autonomy in a mass Age. 1960. New York: Avon, 1971.

[7] Levin, Meyer. The Fanatic. New York: Simon and Schuster, 1956. 
[8] Gilman, Sander L. The Dead Child Speaks: Reading The Diary of Anne Frank. Studies in American-Jewish literature, Vol. 7, No.1 (Spring 1988), pp.9-25: Penn State university Press, 1988. (http://www.jstor.org/stable/41205671).

[9] Hendry, Teressa. "Was Anne Frank's Diary a Hoax?" American Mercury. Summer 1967: 26-28. 